\title{
Immunopathogenesis and neurological manifestations associated to HTLV-1 infection
}

\author{
Anselmo Souza ${ }^{[1],[2],[3]}$, Davi Tanajura ${ }^{[1],[2]}$, Cristina Toledo-Cornel| ${ }^{[1],[3],[4]}$, Silvane Santos ${ }^{[1],[2]}$ \\ and Edgar Marcelino de Carvalho[1]
}

[1]. Serviço de Imunologia, Complexo Hospitalar Universitário Professor Edgard Santos, Universidade Federal da Bahia, Salvador, BA. [2]. Instituto Nacional de Ciência e Tecnologia de Doenças Tropicais, Salvador, BA. [3]. Fogarty International Clinical Research Scholars and Fellows Program, Vanderbilt University, Nashville, Tenesse, USA. [4]. Division of International Medicine and Infectious Diseases, Department of Medicine, Weill Medical College, Cornell University, New York, USA. [5]. Escola Baiana de Medicina e Saúde Pública, Salvador, BA.

\begin{abstract}
The human T lymphotropic virus type-1 (HTLV-1) was the first human retrovirus identified. The virus is transmitted through sexual intercourse, blood transfusion, sharing of contaminated needles or syringes and from mother to child, mainly through breastfeeding. In addition to the well-known association between HTLV-1 and HTLV-1-associated myelopathy/tropical spastic paraparesis (HAM/TSP), several diseases and neurologic manifestations have been associated with the virus. This review was conducted through a PubMed search of the terms HTLV-1, immune response and neurological diseases. Emphasis was given to the most recent data regarding pathogenesis and clinical manifestations of HTLV-1 infection. The aim of the review is to analyze the immune response and the variety of neurological manifestations associated to HTLV-1 infection. A total of 102 articles were reviewed. The literature shows that a large percentage of HTLV-1 infected individuals have others neurological symptoms than HAM/TSP. Increased understanding of these numerous others clinical manifestations associated to the virus than adult T cell leukemia/lymphoma (ATLL) and HAM/TSP has challenged the view that HTLV-1 is a low morbidity infection.
\end{abstract}

Keywords: HTLV-1. Immune response. HAM/TSP. Neurologic disease.

\section{INTRODUCTION}

The human T lymphotropic virus type-1 (HTLV-1) was the first human retrovirus identified ${ }^{1}$. The virus is transmitted through sexual intercourse, blood transfusion, sharing of contaminated needles or syringes and from mother to child, mainly through breastfeeding ${ }^{2,3}$. The infection occurs predominantly in Africa, South America, the Caribbean and southeast Japan, with Brazil being significantly affected ${ }^{3,4}$.

The pathogenesis of HTLV-1 infection is not completely understood, but both $T$ cell activation and proviral load are determinants of disease outcome. The two major diseases associated to the virus infection are adult T cell leukemia/lymphoma (ATLL) and HTLV-1-associated myelopathy/tropical spastic paraparesis $(\mathrm{HAM} / \mathrm{TSP})^{5}$. These clinical manifestations occur in less than $5 \%$ of HTLV- 1 infected patients and have been considered a low morbidity infection. However, several studies showed that a large number of HTLV-1 infected individuals develop symptoms of inflammatory disease ${ }^{6,7}$. Moreover, a large percentage of affected individuals have neurological symptoms other than HAM/TSP ${ }^{8}$.

In this review, the most recent data regarding pathogenesis and neurological manifestations of HTLV-1 infection were analyzed. Emphasis is given to immune response and the variety of neurological diseases associated with HTLV-1 infection.

Address to: Prof. Edgar Marcelino de Carvalho. Serviço de Imunologia/Complexo Hospitalar Universitário Professor Edgard Santos/UFBA. Rua João das Botas s/n, Canela 40110-160 Salvador, BA, Brasil.

Phone: 5571 3237-7353; Fax: 5571 3245-7110

e-mail: edgar@ufba.br

Received in 20/12/2011

Accepted in 14/09/2012
For this review, we examined 398 articles from journals indexed in PubMed. The terms used for the research were: HTLV-1, immune response, HAM/TSP and neurological diseases associated with HTLV-1 infection. Of this total, 102 articles were selected.

\section{STRUCTURE, GENOME AND PERSISTENCE OF THE HTLV-1}

The HTLV-1 genome consists of a single-stranded ribonucleic acid (RNA). The two ends of the genome have long terminal repeats (LTRs) that help in the integration of proviral deoxyribonucleic acid (DNA) into chromosomal DNA. Structural and regulatory genes can be found between the LTRs ${ }^{9}$. The proviral DNA, synthesized by reverse transcription of the viral RNA, has $9 \mathrm{~kb}^{10}$. The genes gag, pol and env encode structural proteins, and the gene tax encodes Tax, a regulatory protein ${ }^{9,11,12}$. The Rex protein, encoded by the gene rex, promotes mRNA translation increasing proliferation and virus dissemination ${ }^{13}$.

Recently, a new gene has been studied: HTLV-1 bZIP factor (HBZ). $\mathrm{HBZ}$ is found at the $3^{\prime}$ end of LTR and encoded by the complementary strand of the HTLV-1 genome ${ }^{14}$. The HBZ messenger RNA (mRNA) is expressed in ATLL cells and its product increases T cell proliferation ${ }^{15}$. $\mathrm{HBZ}$ also participates in the pathogenesis of HAM/TSP as HBZ expression is directly correlated with proviral load ${ }^{16}$.

HTLV-1 preferentially infects cluster of differentiation $4\left(C D 4^{+}\right)$ T cells, but cluster of differentiation $8\left(C D 8^{+}\right)$T cells, dendritic cells, macrophages and other cells are also infected by the virus ${ }^{17-20}$. The ubiquitous glucose transporter-1 (GLUT-1), neuropilin1 (NRP1) and surface heparan sulfate proteoglycans (HSPGs) function as receptors for cell invasion by the virus ${ }^{21}$. Once inside the cell, the virus integrates its DNA into chromosonal DNA. The proviral DNA is transcribed into mRNA and structural proteins are synthesized, creating a new viral particle ${ }^{22}$. Cell-to-cell transmission of HTLV-1 occurs through direct contact. 


\section{IMMUNE RESPONSE TO HTLV-1}

The HTLV-1 infection causes a change in the intracellular environment, which leads to spontaneous activation of infected cells. The protein Tax is responsible for this activation, acting through the transcription nuclear factor kappa-light-chain-enhancer of activated $B$ cells (NFKB). Activated cells also actively transcribe interleukin-2 (IL-2) and interleukin-2 receptor (IL-2R) ${ }^{23}$ leading to intense cell proliferation, particularly T lymphocytes, and spontaneous cytokine production ${ }^{24}$.

Spontaneous cytokine production is seen in both asymptomatic carriers and in patients with HAM/TSP. When compared with asymptomatic carriers, cells from individuals with HAM/TSP produces high levels of interferon- $\gamma$ (IFN- $\gamma$ ) and tumor necrosis factor- $\alpha$ (TNF- $\alpha)^{25}$. Elevated levels of chemokines CXCL10 and CXCL9 are also observed in patients with $\mathrm{HAM} / \mathrm{TSP}^{26,27}$. CD4 ${ }^{+}$and $\mathrm{CD} 8+\mathrm{T}$ cells contribute in similar way to the spontaneous secretion of IL-2, IFN- $\gamma$ and TNF- $\alpha$ in carriers and CD8 T cells are the main source of pro-inflammatory cytokines in HAM/TSP patients ${ }^{25,28}$.

The cytokine profile in response to HTLV-1 infection shows a pattern of Th1 response, with increased TNF and IFN- $\gamma$ production. However, mononuclear cells from asymptomatic carriers produce high levels of regulatory cytokines IL-5 and IL-10 when compared with seronegative individuals ${ }^{29}$. The high IL-10 production in asymptomatic carriers may explain the clinical status of these individuals. The addition of IL-10 to culture of mononuclear cells from asymptomatic carriers decreases the production of IFN- $\gamma$. Such modulation is not observed when exogenous IL-10 is added to culture of mononuclear cell from patients with HAM/TSP ${ }^{30}$.

Cytotoxic CD8 ${ }^{+} \mathrm{T}$ lymphocytes (CTL) are also important in the virustriggered immune response. These cells are chronically activated, are able to recognize the viral protein Tax and are the main host defense mechanism in HTLV-1 infection ${ }^{31,32}$. Progression of viral infection is associated with increased expression of the HBZ gene. Conversely, increasing HBZ protein down modulates Tax expression at the cell surface leading to a decreased CTL efficacy against the virus ${ }^{33}$. However, even in environment of low tax expression, CTLS are still capable of producing high levels of pro-inflammatory cytokines, which is an important factor in the development of HAM/TSP ${ }^{34,35}$. The absence or low expression of co-stimulatory molecules (CD28, CD80, CD86 and CD152) is more frequent in CTLs from HAM/TSP patients than in asymptomatic carriers and healthy subjects ${ }^{36}$.

It is known that the expression of negative immunoregulatory programmed death-1 (PD-1) signaling molecule is involved in the pathogenesis of autoimmune disease and allergy. PD-1 also plays an important role in microbicidal activity ${ }^{37,38}$. Kozako et al. showed that there is a down regulation of PD-1 in HTLV-1-specific CTLs from HTLV-1-infected individuals. The down regulation of PD-1 and the loss of expression of the PD-1 ligand (PD-L1) were also observed in CTLS from patients with HAM/TSP, indicating a state of anergy in these cells, which may contribute to the maintenance of HTLV-1 infection ${ }^{39}$.

Recent studies have shown that dendritic cells (DCs) from patients with HAM/TSP were infected with HTLV-140. DCs are also capable of transmitting the virus to T cells in vitro ${ }^{41}$. Jain et al. showed that DCs exposed to the Tax protein become activated, leading to intense T-cell proliferation and inflammation due to their ability to present antigen to naïve $T$ cells $^{42}$. When evaluating the maturation of monocyte- derived DCs obtained from HTLV-1-infected individuals, Nascimento et al. observed that DCs from healthy subjects displayed an activation profile (increased expression of costimulatory molecules and HLA-DR) absent in DCs from HTLV-1-infected patients ${ }^{20}$.

\section{IMMUNOPATHOGENESIS AND DISEASES ASSOCIATED WITH HTLV-1 INFECTION}

ATLL is an aggressive form of leukemia/lymphoma consisting of oligoclonal or monoclonal outgrowths of CD4+ and CD25+ T-cells ${ }^{43,44}$. According to a Japanese study, the incidence rates of ATLL in HTLV-1 infected patients are $6.6 \%$ and $2.1 \%$ in male and female patients, respectively ${ }^{45}$. Adult T cell leukemia/lymphoma is characterized by the presence of cellular infiltrates affecting the skin, liver, gastrointestinal tract and the lungs ${ }^{46}$. Other characteristics of the disease include hypercalcemia and the presence of flower cells-leukemic cells with multilobulated nuclei on peripheral blood smear ${ }^{46}$. HTLV-1 causes transformation due to the functional role of oncoproteins encoded in its genome. Of these, tax plays a major role in leukemogenesis of ATLL, particularly in the initiation of cellular transformation ${ }^{45}$. Tax constitutively activates NFKB, which is important on leukemogenesis ${ }^{47}$. Tax also contributes to cellular transformation by several other mechanisms, including chromosomal instability, amplification of centrosomes, inducing cell-cycle checkpoint derangements, loss of ability of DNA repair and inhibition of apoptosis in affected cells $s^{48}$.

The Notch signaling pathway, which is involved in cellular proliferation, differentiation and apoptosis, is also activated in ATLL 49,50. Gamma-secretase inhibitors (which control the activation of Notch signaling) use triggered a reduction of tumor cells proliferation, showing the importance of this pathway in ATLL pathogenesis ${ }^{51}$.

The pathogenesis of HAM/TSP is dependent upon both viral and immunological factors (Figure 1). In addition to high proviral load and pro-inflammatory environment discussed previously, HTLV-1 also interferes with cellular function by affecting regulatory $T$ cells (CD4 ${ }^{+} \mathrm{CD} 25^{+}$Foxp $^{+} \mathrm{T}$ cells or T-reg cells). The virus infects T-reg cells and modifies its role in immune regulation. T-reg cell dysfunction coupled to lower production of regulatory cytokines prevents the immune system from down modulating lymphocyte activity in HTLV1 infection. This impairment results in the secretion of high levels of pro-inflammatory cytokines and mediators damaging the spinal cord. Chemokines such as CXCL-9 and CXCL-10 are increased in the serum and in the cerebral spinal fluid of HTLV-1 carriers, and even more pronounced in HAM/TSP patients. These chemokines are responsible for the attraction of activated T cells to the central nervous system (CNS).

In a cross-sectional study comparing HTLV-1 carriers matched by age and sex with seronegative blood bank donors, Caskey et al. showed that xerostomy, periodontal disease, polyarthralgia, arthritis, erectile dysfunction and overactive bladder were significantly higher among HTLV-1 carriers than in controls. In the same study, it was shown that leg weakness, feet numbness, hiperreflexia of the inferior limbs and Babinsky sign were also more frequent in HTLV-1 cases $^{6}$. Furthermore, uveitis, bronchitis and osteoporosis have also been associated with HTLV-1 infection ${ }^{52-54}$. The relationship of these diseases with HTLV-1 has been further explored. For instance, HTLV-1 RNA has been documented in periodontal tissue of patients with chronic periodontitis associated to HTLV-155. Samples of periodontal tissue from patients diagnosed with 
HTLV-1 associated chronic periodontitis displayed a higher expression of IL- $1 \beta$, IFN- $\gamma$ and lower expression of Foxp3 and IL-10 than tissue from patients with chronic periodontitis not associated with the virus ${ }^{55}$.

HTLV-1 associated arthropathy needs to be better characterized both clinically and radiologically. A large number of HTLV-1 carriers as well as patients with HAM/TSP complain of arthralgias and, in a small subset of cases, arthritis is also documented ${ }^{6}$. In the majority of these individuals, the radiologic findings are consistent with osteoarthritis rather than rheumathoid arthritis. However, patients with HTLV-1 associated arthropathy have higher expression of proinflammatory cytokines such as TNF- $\alpha$, IFN- $\gamma$ and IL-6 in the synovial fluid ${ }^{56,57}$. The presence of these cytokines may be explained by the immunological response to the viral antigens at the site of inflammation.

In immunological studies in HTLV-1 infected patients with urinary manifestations of overactive bladder (OAB), immunological parameters were similar to those observed in patients with HAM/ TSP. The immunologic features and proviral load in HTLV-1 carriers, HTLV-1 OAB and HAM/TSP are summarized on Table 1.

These data indicate that HTLV-1 infected patients with urinary manifestations of $O A B$ have proviral load and levels of pro-inflammatory cytokines similar to that observed in HAM/ TSP and higher levels than HTLV-1 carriers. These data suggest that HTLV-1 OAB is either an oligosymptomatic clinical form of HAM/TSP or an early stage of HAM/TSP.

\section{AUTO IMMUNITY VERSUS HYPERSENSITIVITY MEDIATED DISEASE IN HTLV-1}

As HTLV-1 may infect auto reactive cells, it is possible that expansion of these cell clones may lead to autoimmune disease. Several studies have associated HTLV-1 with rheumatoid arthritis, Sjögren's syndrome and polymyositis among other diseases ${ }^{58}$. For instance, the prevalence of HTLV-1 was reported as $23 \%$ in patients with rheumatoid arthritis compared to $3.4 \%$ in the control group ${ }^{59}$. However, this association has not been confirmed by other studies ${ }^{60,61}$. Virus RNA has been documented in synovial tissue from HLTV-1 infected patients. In addition, increased level of pro-inflammatory cytokines is found in the synovial fluid of these patients. Thus, it is likely that hypersensitivity reaction against viral antigen in the synovium contributes to the joint damage in HTLV-1 associated arthropathy.

Dry mouth and to a less extent dry eyes are frequently documented in HTLV-1 infection. Thus, an association of HTLV-1 and Sjögren's disease has been reported. This association was supported by the findings of lymphocyte infiltrates in affected salivary glands in HTLV-1 infected patients ${ }^{62}$. However, most patients lack other clinical features of Sjögren's syndrome such as arthritis. Serological studies of these patients fail to show the presence of autoantibodies SS-A and SS-B, characteristically found in Sjögren's syndrome ${ }^{63}$. On the other hand, sicca syndrome has been observed in several viral infections such as HIV and hepatitis $C^{64}$. As there is no evidence of the presence of autoantibodies or auto reactive T cells in HTLV-1 infected patients diagnosed with sicca syndrome, it is likely that symptoms are caused by a hypersensitivity reaction rather than an autoimmune phenomenon.

\section{NEUROLOGICAL MANIFESTATIONS IN HAM/TSP}

HAM/TSP is caused by damage to the CNS structure, especially in the lower portion of the spinal cord ${ }^{65,66}$. Paraparesis, pyramidal signs and urinary symptoms signs are seeing in almost $100 \%$ of individuals with HAM/TSP, followed by sensory symptoms (50-78\%). Other common complaints are pain and muscle atrophy ${ }^{67,68}$. The development of neurological disability in HAM/TSP occurs mainly during the first year of the disease, and subsequently it becomes relatively stable ${ }^{69}$. However, there are no spontaneous remissions ${ }^{70}$. 


\section{NEUROLOGICAL MANIFESTATIONS OF HTLV-1 PATIENTS WITHOUT HAM/TSP}

In addition to HAM/TSP, other neurologic manifestations have been associated with the virus ${ }^{71}$. Some of these manifestations are related to spinal cord injury and are described as subclinical HAM/TSP like autonomic dysfunctions (overactive bladder, erectile dysfunction, blood pressure and heart rate dysregulation), pyramidal dysfunction (Babinski sign, hyperreflexia, spasticity) and sensory dysfunction (impaired vibratory and proprioceptive function). The WHO diagnostic criteria for HAM/TSP require both the presence of the clinical syndrome of paraparesis with autonomic and sensory abnormalities, positive HTLV-1 serology and confirmation of the presence of HTLV-1 in cerebral-spinal fluid (CSF) ${ }^{72}$. Some authors have proposed classifying patients with neurological symptoms not fulfilling the HAM/TSP criteria as possible or probable HAM/TSP ${ }^{73}$.

There are still other neurological symptoms not related to myelopathy such as cognitive dysfunction (cortical), ataxia (cerebellar), cranial mononeuropathy (cranial nerves), amyotrophic lateral sclerosis (ALS)-like syndrome (motor neuron), polyneuropathy (peripheral nerves) and myopathy (muscles). Some of these symptoms have being found in association with HAM/TSP 67,74 and indicate that the HTLV-1 neurological disease is in fact more than a myelopathy. It is also an inflammatory disease of the entire nervous system.

\section{Autonomic involvement - The overactive bladder}

Overactive bladder is one of the most common neurologic presentations of myelopathy in patients without paraparesis ${ }^{75}$. Nocturia, urgency and incontinence are the most common urinary symptoms with a prevalence that can reach more than $20 \%{ }^{6,76-81}$ (Table 2). Compared with seronegative controls, HTLV-1 carriers have higher frequency of urinary symptoms ${ }^{6,81}$. One study showed that the median length of bladder dysfunction was 61 months, and patients with urinary complaints had a higher median proviral load ${ }^{75}$.

Although overactive bladder has similar features of an urinary tract infection, a cross-sectional study that performed urine culture in HTLV-1 infected subjects concluded that urinary tract infection was present in a minority of cases and the majority of symptoms could be explained by overactive bladder syndrome ${ }^{82}$. Moreover, urodynamic studies found detrusor hyperreflexia in $37 \%$ and $22 \%{ }^{83,84}$, detrusor hyporreflexia in $13 \%{ }^{84}$ and detrusor sphincter dyssynergy in $11 \%^{83}$ of HTLV-1 patients without HAM/TSP. In some cases overactive bladder could precede $\mathrm{HAM} / \mathrm{TSP}$ by years, being the initial manifestation of the disease $\mathrm{e}^{83}$. The importance in the identification of those symptoms is that early treatment with anti-cholinergic and/or catheterization can be instituted and patients should be evaluated for other neurological manifestations.

\section{Autonomic involvement - erectile dysfunction}

Very few studies have evaluated the relationship between HTLV-1 and sexual complaints. Erectile dysfunction (ED) was found as an initial complaint in a 36 year-old HAM/TSP patient ${ }^{85}$. The prevalence of erectile dysfunction in the absence of HAM/TSP varies between 4 and $43 \%$ in the literature ${ }^{6,76}$ (Table 2). When compared with healthy controls, the prevalence in HTLV-1 patients is statistically higher ${ }^{6}$. Furthermore, the prevalence of ED is higher among patients with urinary symptoms and greater neurological disability (EDSS scale) ${ }^{76,86}$.
TABLE 2 - Neurologic characteristics in HTLV-1 patients without HAM/TSP in different studies of the literature.

\begin{tabular}{|c|c|c|}
\hline Neurological symptoms & Prevalence range (\%) & References \\
\hline \multicolumn{3}{|l|}{ Urologic } \\
\hline nocturia & $14.7-29.0$ & $(5,73,74,78)$ \\
\hline urgency & $13.0-26.8$ & $(5,73-76,78)$ \\
\hline incontinence & $7.8-21.6$ & $(5,7,74-76,78)$ \\
\hline frequency & $8.1-15.5$ & $(5,73,78)$ \\
\hline straining/retention & $3.5-13.0$ & $(5,76,77)$ \\
\hline dysuria & $9.5-9.8$ & $(5,74)$ \\
\hline erectile dysfunction & $3.57-43.0$ & $(5,73,77)$ \\
\hline \multicolumn{3}{|l|}{ Weakness } \\
\hline arm & $14.1-16.5$ & $(5,78)$ \\
\hline leg & $12.7-20.8$ & $(5,7,76,78)$ \\
\hline walking difficulty & $5.0-13.0$ & $(5,7,76,78)$ \\
\hline running difficulty & $3.0-16.9$ & $(76,78,88)$ \\
\hline \multicolumn{3}{|l|}{ Sensitive } \\
\hline hand numbness & $31.5-35.2$ & $(5,78)$ \\
\hline foot numbness & $2.68-29.5$ & $(5,76,78,95)$ \\
\hline \multicolumn{3}{|l|}{ Cardiovascular } \\
\hline syncope/Autonomic & $0.59-1.02$ & $(77,95)$ \\
\hline \multicolumn{3}{|l|}{ neurological signs } \\
\hline cranial nerves & $1(2.0)$ & (76) \\
\hline cerebellar & $3(6.0)$ & $(76)$ \\
\hline \multicolumn{3}{|l|}{ Weakness } \\
\hline leg weakness & $0-11.8$ & $(5,75,78,88)$ \\
\hline toe walking & $0.5-10.4$ & $(75,88)$ \\
\hline heel walking & 15.7 & $(75)$ \\
\hline rising of chair & 1.0 & (88) \\
\hline \multicolumn{3}{|l|}{ Reflexes } \\
\hline hyperreflexia & $4.6-34.0$ & $(75-78,87)$ \\
\hline hyporreflexia & 4.59 & (77) \\
\hline babinski & $6.0-10.4$ & $(75,76,78)$ \\
\hline \multicolumn{3}{|l|}{ Sensibility } \\
\hline reduced vibration sense & $0.5-43.8$ & $(75,88,95)$ \\
\hline hypoesthesia & $1.19-5.2$ & $(75-77,95)$ \\
\hline \multicolumn{3}{|l|}{ Equilibrium } \\
\hline Romberg & 0 & $(88)$ \\
\hline tandem gait & $1.5-28.1$ & $(75,88)$ \\
\hline
\end{tabular}

\section{Autonomic involvement - blood pressure and heart rate control}

HAM/TSP patients had an increase in heart rate and lower amplitude in blood pressure when compared with HTLV-1 patients without HAM/TSP and healthy controls ${ }^{87,88}$. In those cases there are both sympathetic and parasympathetic cardiovascular autonomic dysfunction ${ }^{88}$ and disturbance in sympathetic skin response ${ }^{87}$. Also there was correlation between the clinical symptoms and exam alterations ${ }^{87}$.

The low to high frequency ratio was significantly lower in HAM/TSP patients when compared to healthy controls and those 
with thoracic cord atrophy had lower ratios, suggesting reduced cardiovascular sympathetic activity ${ }^{89}$.

\section{Isolated pyramidal signs}

In the literature, hyperreflexia was found to be prevalent with a range from 4.6 to $34 \%{ }^{78}$, Babinski sign was not common and has been seen in 6 to $10.4 \%^{78-81,90}$ (Table 2). Objective leg weakness is described in some studies and can reach a prevalence of $10 \% 6,78,81,91$. Some of those pyramidal signs appear as an isolated form and some combined with urinary and erectile dysfunction ${ }^{80}$, but not fulfilling the formal criteria for HAM/TSP. Interestingly in two cohort studies involving children with HTLV-1 a high prevalence of hyperreflexia was found and there was a strong relation with skin diseases (infective dermatitis, seborrhea, eczema) and anemia ${ }^{79,90}$.

\section{Isolated sensory symptoms}

To be compatible with diagnosis of myelopathy the sensory symptoms have to follow a specific pattern on physical examination. In the HAM/TSP criteria vibration sense is the modality with the most impairment, probably due to lesions in the dorsal columns of the spinal cord. Other symptoms like numbness and hand and feet paresthesias are more compatible with a polyneuropathy syndrome. A prevalence of $43.8 \%$ in vibration sense impairment was found in one study, which was statistically different from healthy subjects. In this study, however, trained nurses performed the physical exams rather than neurologists, which may have affected the prevalence estimate $^{78}$.

\section{HTLV-1 AND NON-MYELOPATHY NERVOUS SYSTEM DISEASE}

\section{Cognitive dysfunction}

HAM/TSP and non-HAM/TSP HTLV-1 patients had a lower performance in neuropsychological tests when compared to controls. In HTLV-1 patients without HAM/TSP, impairment was found in verbal and visual memory, attention and visual motor abilities ${ }^{92}$. There was no association between brain magnetic resonance imaging findings and cognitive dysfunction assessed by the Mini-Mental State Exam in one small study ${ }^{93}$.

\section{Cranial neuropathy}

Few articles, generally case reports, have described an association between cranial neuropathy, usually facial nerve (VII cranial nerve) and HTLV-1. In one Caribbean study of 62 consecutive patients with facial nerve palsy the prevalence of HTLV-1 seropositivity was $20.7 \%{ }^{94}$.

\section{Cerebellar syndrome}

Only case reports describe cerebellar manifestations in HTLV-1 patients. New onset loss of balance, wide-based stance and gait-truncal instability, and mild leg ataxia (vermian cerebellar syndrome), with absent upper limb dysmetria but with postural tremor, downbeat nystagmus, and dysarthria have been described ${ }^{95}$. In all cases, patients progressed to HAM/TSP characterizing a spinocerebellar syndrome ${ }^{95,96}$.

\section{Amyotrophic lateral sclerosis - like syndrome}

A few studies have found an association between amyotrophic lateral sclerosis (ALS)-like syndrome and HTLV-1 ${ }^{97}$. However, in those cases, the clinical presentation and progression of ALS-like syndrome was different than ALS, including long-term survival, absence of characteristic pathological findings (Bunina bodies in ALS) and presence of overactive bladder.

\section{Polyneuropathy}

A recent electrodiagnostic study in 73 patients with HAM/TSP found a prevalence of peripheral nerve involvement of $30 \%$, with all patients demonstrating predominantly axonal neuropathy ${ }^{74}$. Sensorymotor polyneuropathy was the most common neuropathy observed in this study ${ }^{74}$. Investigators have reported a prevalence of $34 \%$ of peripheral nervous system involvement and $6 \%$ of polyneuropathy in patients without HAM/TSP98.

\section{Myopathy}

Two types of HTLV-1 associated myopathy have been described: inclusion body myositis ${ }^{99}$ and polymyositis ${ }^{100-102}$. Generally those patients do not present with HAM/TSP and response to treatment is poor ${ }^{99,100}$.

\section{Conclusions}

Advances in recent years have allowed to a better understanding of HTLV-1 infection and lead to a better characterization of its myriad associated clinical manifestations. Both the HTLV-1 virus and the failure of regulatory mechanisms in the immunological responses by the host immune system play a pivotal role in the maintenance of $T$ cell activation. When $T$ cell activation persists, tissue damage occurs. The recognition that the majority of HTLV-1 individuals have diseases other than HAM/TSP and ATLL and that a large percentage of HTLV-1 infected subjects previously considered carriers have neurological manifestations strongly suggest that HTLV-1 is associated with greater morbidity than previously thought.

\section{CONFLICT OF INTEREST}

The authors declare that there is no conflict of interest.

\section{ABSTRACT IN PORTUGUESE}

\section{Imunopatogênese e manifestações neurológicas associadas} à infecção pelo HTLV-1

O vírus linfotrópico de células T humanas do tipo 1 (HTLV-1) foi o primeiro retrovírus humano identificado. $O$ vírus é transmitido via relação sexual, transfusão de sangue, compartilhamento de agulhas ou seringas contaminadas ou da mãe para o filho, principalmente através da amamentação. Além da conhecida associação entre o HTLV-1 e a mielopatia associada ao HTLV-1 (HAM/TSP), várias doenças e manifestações neurológicas tem sido associadas com o vírus. Esta revisão de literatura foi conduzida através de pesquisa ao banco de dados do PubMed, com os termos HTLV-1, resposta imune e doenças neurológicas. Foram enfatizados os dados mais recentes sobre a patogênese e às manifestações clínicas na infecção pelo HTLV-1. O objetivo dessa revisão é analisar a resposta imune e a variedade de manifestações neurológicas associadas com a infecção pelo HTLV-1. 
Um total de 102 artigos foi analisado. A literatura mostra que grande porcentagem de indivíduos infectados pelo HTLV-1 apresenta sintomas neurológicos mesmo na ausência de HAM/TSP. Uma maior compreensão das várias manifestações clínicas associadas ao vírus, além da leucemia/linfoma de células T do adulto (ATLL) e HAM/TSP, auxilia a estabelecer que, na realidade, a infecção pelo vírus possui uma morbidade maior do que se pensava.

Palavras-chaves: HTLV-1. Resposta imune. HAM/TSP. Doença neurológica.

\section{REFERENCES}

1. Poiesz BJ, Ruscetti FW, Gazdar AF, Bunn PA, Minna JD, Gallo RC. Detection and isolation of type $C$ retrovirus particles from fresh and cultured lymphocytes of a patient with cutaneous T-cell lymphoma. Proc Natl Acad Sci USA 1980; 77:7415-7419.

2. Bittencourt AL. Vertical transmission of HTLV-I/II: a review. Rev Inst Med Trop Sao Paulo 1998; 40:245-251.

3. Proietti FA, Carneiro-Proietti AB, Catalan-Soares BC, Murphy EL. Global epidemiology of HTLV-I infection and associated diseases. Oncogene 2005; 24:6058-6068.

4. Carneiro-Proietti AB, Ribas JG, Catalan-Soares BC, Martins ML, Brito-Melo $\mathrm{GE}$, Martins-Filho OA, et al. Infection and disease caused by the human T cell lymphotropic viruses type I and II in Brazil. Rev Soc Bras Med Trop 2002; 35:499-508.

5. Uchiyama T. Human T cell leukemia virus type I (HTLV-I) and human diseases. Ann Rev Immunol 1997;15:15-37.

6. Caskey MF, Morgan DJ, Porto AF, Giozza SP, Muniz AL, Orge GO, et al. Clinical manifestations associated with HTLV type I infection: a cross-sectional study. AIDS Res Hum Retroviruses 2007; 23:365-371.

7. Murphy EL, Wang B, Sacher RA, Fridey J, Smith JW, Nass CC, et al. Respiratory and urinary tract infections, arthritis, and asthma associated with HTLV-I and HTLV-II infection. Emerg Infect Dis 2004; 10:109-116.

8. Morgan DJ, Caskey MF, Abbehusen C, Oliveira-Filho J, Araujo C, Porto AF, et al. Brain magnetic resonance Imaging white matter lesions are frequent in HTLV-I carriers and do not discriminate from HAM/TSP. AIDS Res Hum Retroviruses 2007; 23:1499-1503.

9. Yoshida M. Multiple viral strategies of HTLV-1 for dysregulation of cell growth control. Annu Rev Immunol 2001; 19:475-496.

10. Seiki M, Hattori S, Hirayama Y, Yoshida M. Human adult T-cell leukemia virus: complete nucleotide sequence of the provirus genome integrated in leukemia cell DNA. Proc Natl Acad Sci USA 1983; 80:3618-3622.

11. Kiyokawa T, Seiki M, Imagawa K, Shimizu F, Yoshida M. Identification of a protein ( $p 40 x$ ) encoded by a unique sequence $\mathrm{pX}$ of human T-cell leukemia virus type I. Gann 1984; 75:747-751.

12. Lee TH, Coligan JE, Sodroski JG, Haseltine WA, Salahuddin SZ, Wong-Staal F, et al. Antigens encoded by the 3 '-terminal region of human T-cell leukemia virus: evidence for a functional gene. Science 1984; 226:57-61.

13. Younis I, Green PL. The human T-cell leukemia virus Rex protein. Front Biosci 2005; 10:431-445.

14. Gaudray G, Gachon F, Basbous J, Biard-Piechaczyk M, Devaux C, Mesnard JM. The complementary strand of the human T-cell leukemia virus type 1 RNA genome encodes a bZIP transcription factor that down-regulates viral transcription. J Virol 2002; 76:12813-12822.

15. Mesnard JM, Barbeau B, Devaux C. HBZ, a new important player in the mystery of adult T-cell leukemia. Blood 2006; 108:3979-3982.

16. Saito $M$, Matsuzaki T, Satou $Y$, Yasunaga J, Saito $K$, Arimura $K$, et al. In vivo expression of the HBZ gene of HTLV-1 correlates with proviral load, inflammatory markers and disease severity in HTLV-1 associated myelopathy/tropical spastic paraparesis (HAM/TSP). Retrovirology 2009; 6:19.

17. Revel T, Mabondzo A, Gras G, Delord B, Roques P, Boussin F, et al. In vitro infection of human macrophages with human T-cell leukemia virus type 1. Blood 1993; 81:1598-1606.
18. Knight SC, Macatonia SE, Cruickshank K, Rudge P, Patterson S. Dendritic cells in HIV-1 and HTLV-1 infection. Adv Exp Med Biol 1993; 329:545-549.

19. Yamano Y, Cohen CJ, Takenouchi N, Yao K, Tomaru U, Li HC, et al. Increased expression of human T lymphocyte virus type I (HTLV-I) Tax11-19 peptidehuman histocompatibility leukocyte antigen A*201 complexes on CD4+ $\mathrm{CD} 25+\mathrm{T}$ Cells detected by peptide-specific, major histocompatibility complex-restricted antibodies in patients with HTLV-I-associated neurologic disease. J Exp Med 2004; 199:1367-1377.

20. Nascimento CR, Lima MA, Andrada Serpa MJ, Espindola O, Leite AC, Echevarria-Lima J. Monocytes from HTLV-1-infected patients are unable to fully mature into dendritic cells. Blood 2011; 117:489-499.

21. Manel N, Kinet S, Kim FJ, Taylor N, Sitbon M, Battini JL. GLUT-1 is the receptor of retrovirus HTLV. Med Sci 2004; 20:277-279.

22. Manel N, Battini JL, Taylor N, Sitbon M. HTLV-1 tropism and envelope receptor. Oncogene 2005; 24:6016-6025.

23. Ballard DW, Bohnlein E, Lowenthal JW, Wano Y, Franza BR, Greene WC. HTLV-I tax induces cellular proteins that activate the kappa B element in the IL-2 receptor alpha gene. Science 1988; 241:1652-1655.

24. Jacobson S, Zaninovic V, Mora C, Rodgers-Johnson P, Sheremata WA, Gibbs Jr CJ, et al. Immunological findings in neurological diseases associated with antibodies to HTLV-I: activated lymphocytes in tropical spastic paraparesis. Ann Neurol 1988; 23 (suppl):196-200.

25. Santos SB, Porto AF, Muniz AL, Jesus AR, Magalhaes E, Melo A, et al. Exacerbated inflammatory cellular immune response characteristics of HAM/ TSP is observed in a large proportion of HTLV-I asymptomatic carriers. BMC Infect Dis 2004; 4:7.

26. Guerreiro JB, Santos SB, Morgan DJ, Porto AF, Muniz AL, Ho JL, et al. Levels of serum chemokines discriminate clinical myelopathy associated with human T lymphotropic virus type 1 (HTLV-1)/tropical spastic paraparesis (HAM/TSP) disease from HTLV-1 carrier state. Clin Exp Immunol 2006; 145:296-301.

27. Narikawa K, Fujihara K, Misu T, Feng J, Fujimori J, Nakashima I, et al. CSFchemokines in HTLV-I-associated myelopathy: CXCL10 up-regulation and therapeutic effect of interferon-alpha. J Neuroimmunol 2005; 159:177-182.

28. Goon PK, Igakura T, Hanon E, Mosley AJ, Asquith B, Gould KG, et al. High circulating frequencies of tumor necrosis factor alpha- and interleukin2-secreting human T-lymphotropic virus type 1 (HTLV-1)-specific CD4+ T cells in patients with HTLV-1-associated neurological disease. J Virol 2003; 77:9716-9722.

29. Carvalho EM, Bacellar O, Porto AF, Braga S, Galvão-Castro B, Neva F. Cytokine profile and immunomodulation in asymptomatic human T-lymphotropic virus type 1-infected blood donors. J Acquir Immune Defic Syndr 2001; 27:1-6.

30. Santos SB, Porto AF, Muniz AL, Luna T, Nascimento MC, Guerreiro JB, et al. Modulation of T cell responses in HTLV-1 carriers and in patients with myelopathy associated with HTLV-1. Neuroimmunomodulation 2006; 13:145-151.

31. Hanon E, Hall S, Taylor GP, Saito M, Davis R, Tanaka Y, et al. Abundant tax protein expression in $\mathrm{CD} 4+\mathrm{T}$ cells infected with human T-cell lymphotropic virus type I (HTLV-I) is prevented by cytotoxic T lymphocytes. Blood 2000; 95:1386-1392.

32. Nishiura $Y$, Nakamura T, Ichinose $K$, Shirabe $S$, Tsujino A, Goto $H$, et al. Increased production of inflammatory cytokines in cultured CD4+ cells from patients with HTLV-I-associated myelopathy. Tohoku J Exp Med 1996; 179:227-233.

33. Macnamara A, Rowan A, Hilburn S, Kadolsky U, Fujiwara H, Suemori K, et al. HLA class I binding of HBZ determines outcome in HTLV-1 infection. PLoS Pathog 2010; 6:e1001117.

34. Biddison WE, Kubota R, Kawanishi T, Taub DD, Cruikshank WW, Center DM, et al. Human T cell leukemia virus type I (HTLV-I)-specific CD8+ CTL clones from patients with HTLV-I-associated neurologic disease secrete proinflammatory cytokines, chemokines, and matrix metalloproteinase. J Immunol 1997; 159:2018-2025. 
35. Kubota R, Kawanishi T, Matsubara H, Manns A, Jacobson S. Demonstration of human T lymphotropic virus type I (HTLV-I) tax-specific CD8+ lymphocytes directly in peripheral blood of HTLV-I-associated myelopathy/ tropical spastic paraparesis patients by intracellular cytokine detection. J Immunol. 1998; 161:482-488.

36. Sabouri AH, Usuku K, Hayashi D, Izumo S, Ohara Y, Osame M, et al. Impaired function of human T-lymphotropic virus type 1 (HTLV-1)-specific CD8+ T cells in HTLV-1-associated neurologic disease. Blood 2008; 112:2411-2420.

37. Blank C, Mackensen A. Contribution of the PD-L1/PD-1 pathway to T-cell exhaustion: an update on implications for chronic infections and tumor evasion. Cancer Immunol Immunother 2007; 56:739-745.

38. Sharpe AH, Wherry EJ, Ahmed R, Freeman GJ. The function of programmed cell death 1 and its ligands in regulating autoimmunity and infection. Nat Immunol 2007; 8:239-245.

39. Kozako $T$, Yoshimitsu M, Akimoto $M$, White $Y$, Matsushita $K$, Soeda $S$, et al. Programmed death-1 (PD-1)/PD-1 ligand pathway-mediated immune responses against human T-lymphotropic virus type 1 (HTLV-1) in HTLV1-associated myelopathy/tropical spastic paraparesis and carriers with autoimmune disorders. Hum Immunol 2011; 72:1001-1006.

40. Macatonia SE, Cruickshank JK, Rudge P, Knight SC. Dendritic cells from patients with tropical spastic paraparesis are infected with HTLV-1 and stimulate autologous lymphocyte proliferation. AIDS Res Hum Retroviruses 1992; 8:1699-1706.

41. Jones KS, Petrow-Sadowski C, Huang YK, Bertolette DC, Ruscetti FW. Cell-free HTLV-1 infects dendritic cells leading to transmission and transformation of CD4(+) T cells. Nat Med 2008; 14:429-436.

42. Jain P, Ahuja J, Khan ZK, Shimizu S, Meucci O, Jennings SR, et al. Modulation of dendritic cell maturation and function by the Tax protein of human $T$ cell leukemia virus type 1. J Leukoc Biol 2007; 82:44-56.

43. Higuchi M, Fujii M. Distinct functions of HTLV-1 Tax1 from HTLV-2 Tax2 contribute key roles to viral pathogenesis. Retrovirology 2009; 6:117.

44. Shembade N, Harhaj EW. Role of post-translational modifications of HTLV-1 Tax in NF-êB activation. World J Biol Chem 2010; 1:13-20.

45. Matsuoka M, Jeang KT. Human T-cell leukemia virus type 1 (HTLV-1) and leukemic transformation: viral infectivity, Tax, HBZ and therapy. Oncogene 2010; 30:1379-1389.

46. Matsuoka M. Human T-cell leukemia virus type I (HTLV-I) infection and the onset of adult T-cell leukemia (ATL). Retrovirology 2005; 2:27.

47. Qu Z, Xiao G. Human T-Cell lymphotropic virus: a model of NF-êB-associated tumorigenesis. Viruses 2011; 3:714-749.

48. Matsuoka M, Jeang KT. Human T-cell leukaemia virus type 1 (HTLV-1) infectivity and cellular transformation. Nat Rev Cancer 2007; 7:270-280.

49. Artavanis-Tsakonas S, Rand MD, Lake RJ. Notch signaling: cell fate control and signal integration in development. Science 1999; 284:770-776.

50. D'Souza B, Miyamoto A, Weinmaster G. The many facets of Notch ligands. Oncogene 2008; 27:5148-167.

51. Pancewicz J, Taylor JM, Datta A, Baydoun HH, Waldmann TA, Hermine O, et al. Notch signaling contributes to proliferation and tumor formation of human T-cell leukemia virus type 1-associated adult T-cell leukemia. Proc Natl Acad Sci USA 2010; 107:16619-16624.

52. Kimura I. HABA (HTLV-I associated bronchiolo-alveolar disorder). Nihon Kyobu Shikkan Gakkai Zasshi 1992; 30:787-795.

53. Pinheiro SR, Lana-Peixoto MA, ProiettiAB, Orefice F, Lima-Martins MV, Proietti FA. HTLV-I associated uveitis, myelopathy, rheumatoid arthritis and Sjogren's syndrome. Arq Neuropsiquiatr 1995; 53:777-781.

54. Schachter D, Cartier L, Borzutzky A. Osteoporosis in HTLV-I-associated myelopathy/tropical spastic paraparesis (HAM/TSP). Bone 2003; 33:192196.

55. Garlet GP, Giozza SP, Silveira EM, Claudino M, Santos SB, Avila-Campos $\mathrm{MJ}$, et al. Association of human T lymphotropic virus 1 amplification of periodontitis severity with altered cytokine expression in response to a standard periodontopathogen infection. Clin Infect Dis 2010; 50:e11-18.
56. Eguchi K, Nakamura T, Mine M, Ida H, Kawakami A, Migita K, et al. HTLV-I associated arthritis: characteristics of an HTLV-I virus infected T cell line from synovial fluid. Ann Rheum Dis 1992; 51:673-677.

57. Yin W, Hasunuma T, Kobata T, Sumida T, Nishioka K. Synovial hyperplasia in HTLV-I associated arthropathy is induced by tumor necrosis factor-alpha produced by HTLV-I infected CD68+ cells. J Rheumatol 2000; 27:874-881.

58. Yu H, Higa F, Yamadori I, Yara S, Tanimoto Y, Haranaga S, et al. Pulmonary complications in human T-cell lymphotropic virus type 1 carriers with Sjogren's syndrome, three case reports and literature review. Rheumatol Int 2009; 30:253258.

59. Hida A, Imaizumi M, Sera N, Akahoshi M, Soda M, Maeda R, et al. Association of human T lymphotropic virus type I with Sjogren syndrome. Ann Rheum Dis 2010; 69:2056-2057.

60. Bailer RT, Lazo A, Harisdangkul V, Ehrlich GD, Gray LS, Whisler RL, et al. Lack of evidence for human T cell lymphotrophic virus type I or II infection in patients with systemic lupus erythematosus or rheumatoid arthritis. J Rheumatol 1994; 21:2217-2224.

61. Sebastian D, Nayiager S, York DY, Mody GM. Lack of association of Human T-cell lymphotrophic virus type 1 (HTLV-1) infection and rheumatoid arthritis in an endemic area. Clin Rheumatol 2003; 22:30-32.

62. Nakamura H, Kawakami A, Tominaga M, Hida A, Yamasaki S, Migita K, et al. Relationship between Sjogren's syndrome and human T-lymphotropic virus type I infection: follow-up study of 83 patients. J Lab Clin Med 2000; 135:139-144.

63. Ferraz-Chaoui AK, Atta AM, Atta ML, Galvão-Castro B, Santiago MB. Study of autoantibodies in patients with keratoconjunctivitis sicca infected by the human T cell lymphotropic virus type 1 . Rheumatol Int 2010; 30:775-778.

64. Vitali C. Immunopathologic differences of Sjogren's syndrome versus sicca syndrome in HCV and HIV infection. Arthritis Res Ther 2011; 13:233.

65. Bangham CR. HTLV-1 infections. J Clin Pathol 2000; 53:581-586.

66. Ribas JG, Melo GC. Human T-cell lymphotropic virus type 1(HTLV-1)associated myelopathy. Rev Soc Bras Med Trop 2002; 35:377-384.

67. Carod-Artal FJ, Mesquita HM, Ribeiro LS. Neurological symptoms and disability in HTLV-1 associated myelopathy. Neurologia 2008; 23:78-84.

68. Champs AP, Passos VM, Barreto SM, Vaz LS, Ribas JG. [HTLV-1 associated myelopathy: clinical and epidemiological profile in a 10 -year case series study]. Rev Soc Bras Med Trop 2010; 43:668-672.

69. Araujo A, Lima MA, Silva MTT. Human T-lymphotropic virus 1 neurologic disease. Curr Treat Options Neurol 2008; 10:193-200.

70. Araujo AQ, Leite AC, Dultra SV, Andrada-Serpa MJ. Progression of neurological disability in HTLV-I-associated myelopathy/tropical spastic paraparesis (HAM/TSP). J Neurol Sci 1995; 129:147-151.

71. Araujo AQ, Silva MT. The HTLV-1 neurological complex. Lancet Neurol 2006; 5:1068-1076.

72. Osame M. Review of WHO Kagoshima meeting and diagnostic guidelines for HAM/TSP. New York: Blattner WA; 1990.

73. Castro-Costa CM, Araujo AQ, Barreto MM, Takayanagui OM, Sohler MP, Silva EL, et al. Proposal for diagnostic criteria of tropical spastic paraparesis/ HTLV-I-associated myelopathy (TSP/HAM). AIDS Res Hum Retroviruses 2006; 22:931-935.

74. Saeidi M, Sasannejad P, Foroughipour M, Shahami S, Shoeibi A. Prevalence of peripheral neuropathy in patients with HTLV-1 associated myelopathy/ tropical spastic paraparesis (HAM/TSP). Acta Neurol Belg 2011; 111:41-44.

75. Silva MT, Coutinho F, Leite AC, Harab RC, Araujo A, Andrada-Serpa MJ. Isolated bladder dysfunction in human T lymphotropic virus type 1 infection. Clin Infect Dis 2009; 48:e34-36.

76. Castro N, Oliveira P, Freitas D, Rodrigues W, Muniz A, Carvalho E. Erectile dysfunction and HTLV-I infection: a silent problem. Int J Impot Res 2005; 17:364-369.

77. Castro NM, Rodrigues Jr W, Freitas DM, Muniz A, Oliveira P, Carvalho EM. Urinary symptoms associated with human T-cell lymphotropic virus type I infection: evidence of urinary manifestations in large group of HTLV-I carriers. Urology 2007; 69:813-818. 
78. Biswas HH, Engstrom JW, Kaidarova Z, Garratty G, Gibble JW, Newman BH, et al. Neurologic abnormalities in HTLV-I- and HTLV-II-infected individuals without overt myelopathy. Neurology 2009; 73:781-789.

79. Kendall EA, González E, Espinoza I, Tipismana M, Verdonck K, Clark D, et al. Early neurologic abnormalities associated with human T-cell lymphotropic virus type 1 infection in a cohort of Peruvian children. J Pediatr 2009; 155:700-706.

80. Leite A. Neurological manifestations in HTLV-I-infected blood donors. J Neurol Sci 2003; 214:49-56.

81. Poetker SKW, Porto AF, Giozza SP, Muniz AL, Caskey MF, Carvalho EM, et al. Clinical manifestations in individuals with recent diagnosis of HTLV type I infection. J Clin Virol 2011; 51:54-58

82. Rocha PN, Rehem AP, Santana JF, Castro N, Muniz AL, Salgado K, et al. The cause of urinary symptoms among human T lymphotropic virus type I (HLTV-I) infected patients: a cross sectional study. BMC Infect Dis 2007; 7:15.

83. Castro NM, Freitas DM, Rodrigues Jr W, Muniz A, Oliveira P, Carvalho EM. Urodynamic features of the voiding dysfunction in HTLV-1 infected individuals (discussion 244-245). Int Braz J Urol 2007; 33:238-244.

84. Lima CL, Rabolini G, Menna-Barreto M, Santos EB, Koff WJ. Urodynamic alterations in patients with HTLV-1 infection (discussion 6-7). Int Braz J Urol 2002; 28:452-456.

85. Oliveira JT, Carneiro-Proietti AB, Lima-Martins MV, Martins ML, Proietti FA. Erectile insufficiency as first symptom of HTLV I/II associated myelopathy. Case report. Arq Neuropsiquiatr 1998; 56:123-125.

86. Oliveira P, Castro NM, Muniz AL, Tanajura D, Brandão JC, Porto AF, et al. Prevalence of erectile dysfunction in HTLV-1-infected patients and its association with overactive bladder. Urology 2010; 75:1100-1103.

87. Alamy AH, Menezes FB, Leite AC, Nascimento OM, Araujo AQ. Dysautonomia in human T-cell lymphotrophic virus type I-associated myelopathy/tropical spastic paraparesis. Ann Neurol 2001; 50:681-685.

88. Ohishi K, Nagasato K, Aoi W, Nakamura T, Ichinose K, Nishiura Y, et al. Circadian rhythms of blood pressure and heart rate in patients with human T-lymphotropic virus type-I-associated myelopathy. Tohoku J Exp Med 1993; 169:67-75.

89. Kuriyama N, Niwa F, Watanabe Y, Yamada K, Tokuda T, Mizuno T, et al. Evaluation of autonomic malfunction in HTLV-1 associated myelopathy (HAM). Auton Neurosci 2009; 150:131-135.

90. Maloney EM, Wiktor SZ, Palmer P, Cranston B, Pate EJ, Cohn S, et al. A cohort study of health effects of human T-cell lymphotropic virus type I infection in Jamaican children. Pediatrics 2003; 112:e136-142.
91. Murphy EL, Wilks R, Morgan OS, Hanchard B, Cranston B, Figueroa JP, et al. Health effects of human T-lymphotropic virus type I (HTLV-I) in a Jamaican cohort. Int J Epidemiol 1996; 25:1090-1097.

92. Silva MT, Mattos P, Alfano A, Araujo AQ. Neuropsychological assessment in HTLV-1 infection: a comparative study among TSP/HAM, asymptomatic carriers, and healthy controls. J Neurol Neurosurg Psychiatry 2003; 74:1085-1089.

93. Morgan DJ, Caskey MF, Abbehusen C, Oliveira-Filho J, Araujo C, Porto AF, et al. Brain magnetic resonance imaging white matter lesions are frequent in HTLV-I carriers and do not discriminate from HAM/TSP. AIDS Res Hum Retroviruses 2007; 23:1499-1504.

94. Bartholomew C, Cleghorn F, Jack N, Edwards J, Blattner W. Human T-cell lymphotropic virus type I-associated facial nerve palsy in Trinidad and Tobago. Ann Neurol 1997; 41:806-809.

95. Castillo LC, Gracia F, Román GC, Levine P, Reeves WC, Kaplan J. Spinocerebellar syndrome in patients infected with human T-lymphotropic virus types I and II (HTLV-I/HTLV-II): report of 3 cases from Panama. Acta Neurol Scand 2000; 101:405412.

96. Carod-Artal FJ, Negro MC, Vargas AP, Rizzo I. Cerebellar syndrome and peripheral neuropathy as manifestations of infection by HTLV-1 human T-cell lymphotropic virus. Rev Neurol 1999; 29:932-935.

97. Silva MT, Leite AC, Alamy AH, Chimelli L, Andrada-Serpa MJ, Araujo AQ. ALS syndrome in HTLV-I infection. Neurology 2005; 65:1332-1333.

98. Leite AC, Silva MT, Alamy AH, Afonso CR, Lima MD, Andrada-Serpa MJ, et al. Peripheral neuropathy in HTLV-I infected individuals without tropical spastic paraparesis/HTLV-I-associated myelopathy. J Neurol 2004;251:877-881.

99. Matsuura E, Umehara F, Nose H, Higuchi I, Matsuoka E, Izumi K, et al. Inclusion body myositis associated with human T-lymphotropic virus-type I infection: eleven patients from an endemic area in Japan. J Neuropathol Exp Neurol 2008; 67:41-49.

100. Gilbert DT, Morgan O, Smikle MF, Simeon D, Barton EN. HTLV-1 associated polymyositis in Jamaica. Acta Neurol Scand 2001; 104:101-104.

101. Oliveira HA, Macieira JC, Fakhouri R. Polymyositis and HTLV-I infection: case report. Arq Neuropsiquiatr 2000; 58:935-938.

102. Scola RH, Werneck LC, Heinig ME, Milano JB, Almeida SM, Arruda WO. Inflammatory myopathy on HTLV-I infection: case report. Arq Neuropsiquiatr 2001; 59:119-122. 